\title{
Fine-needle aspiration accuracy in the diagnosis of primary epithelioid angiosarcoma of the adrenal gland: a case report and review of the literature
}

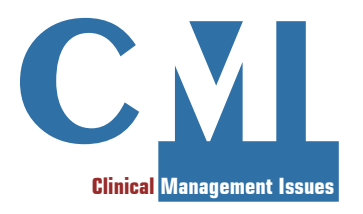

Case report

Tullio Torelli ${ }^{1}$, Stefano Radaelli ${ }^{2}$, Maurizio Colecchia $^{3}$, Biagio Paolini ${ }^{3}$, Mario Acbille Catanzaro ${ }^{1}$, Nicola Nicolai ${ }^{1}$, Davide Biasoni ${ }^{1}$, Luigi Piva ${ }^{1}$, Silvia Stagni ${ }^{1}$, Roberto Salvioni ${ }^{1}$

\begin{abstract}
Primary epithelioid angiosarcoma of the adrenal gland is extremely rare. Only 37 cases have been reported in the scientific literature.

Here we describe the case of a 55-year-old woman affected by metastatic angiosarcoma in the right adrenal gland, who died few days after the histological diagnosis made by fine-needle aspiration (FNA). This is the second case of primary epithelioid angiosarcoma diagnosed by FNA among scientific articles published in English in PubMed. Microscopically, the tumor showed a predominant epithelioid differentiation, thus making the diagnostic process more difficult than usual. Immunohistochemical examination revealed positive reactivity for cytokeratin, CD31, and CD34. The literature shows that epithelioid adrenal angiosarcoma has poor clinical outcome, especially when metastatic at presentation.
\end{abstract}

Keywords: Adrenal glands; Hemangiosarcoma; Biopsy, Fine-Needle; Primary Epithelioid Angiosarcoma; Fine-Needle Aspiration

Accuratezza diagnostica dell'agobiopsia nell'angiosarcoma epitelioide primario della ghiandola surrenale: caso clinico e revierw della letteratura

CMI 2017; 11(1): 7-16

http://dx.doi.org/10.7175/cmi.v11i1.1256

\section{INTRODUCTION}

Angiosarcomas are malignant tumors arising from the endothelial lining of blood vessels and accounting for less than $1 \%$ of all soft tissue sarcomas, which represent $1 \%$ of all solid tumors in adults. That means that the incidence of angiosarcoma is 0.1$0.2 / 100,000$ per year. Adrenal gland is an uncommon site for angiosarcoma. Usually, it occurs in skin, soft tissue, breast, bone, liver, and spleen and has poor long-term prognosis [1]. No predisposing factors for primary adrenal angiosarcoma have been identified yet.

\section{CASE REPORT}

A 55-year-old woman was admitted to our Urology Unit on January 2014 to undergo a biopsy of right adrenal mass. Clinically, the patient suffered from continuous pain in the right lumbar region, a significant weight loss in the past two months (about $15 \mathrm{~kg}$ ), and severe asthenia. Before hospitalization,

Why we describe this case

Epithelioid angiosarcoma of the adrenal gland is a very rare and aggressive tumor, with no specific clinical or radiological patterns. Diagnosis requires detailed pathologic examination accompanied by immunohistochemical studies using endothelial markers. When FNA is used for diagnosis, this process becomes much challenging due to the minimal amount of tissue available for examination
Department of Urology, IRCCS Istituto Nazionale dei Tumori, Milan, Italy 2 Department of Surgery, Melanoma and Sarcoma, IRCSS Istituto Nazionale dei Tumori, Milan, Italy 3 Department of Pathology, IRCCS Istituto Nazionale dei Tumori, Milan, Italy
Corresponding author Tullio Torelli tullio.torelli@istitutotumori.mi.it

Disclosure

The authors declare they have no competing financial interests concerning the topics of this article 


\section{Figure 1.}

Ultrasonography showing right adrenal mass (red arrow) infiltrating the upper pole of kidney and liver (one month before hospital admission)
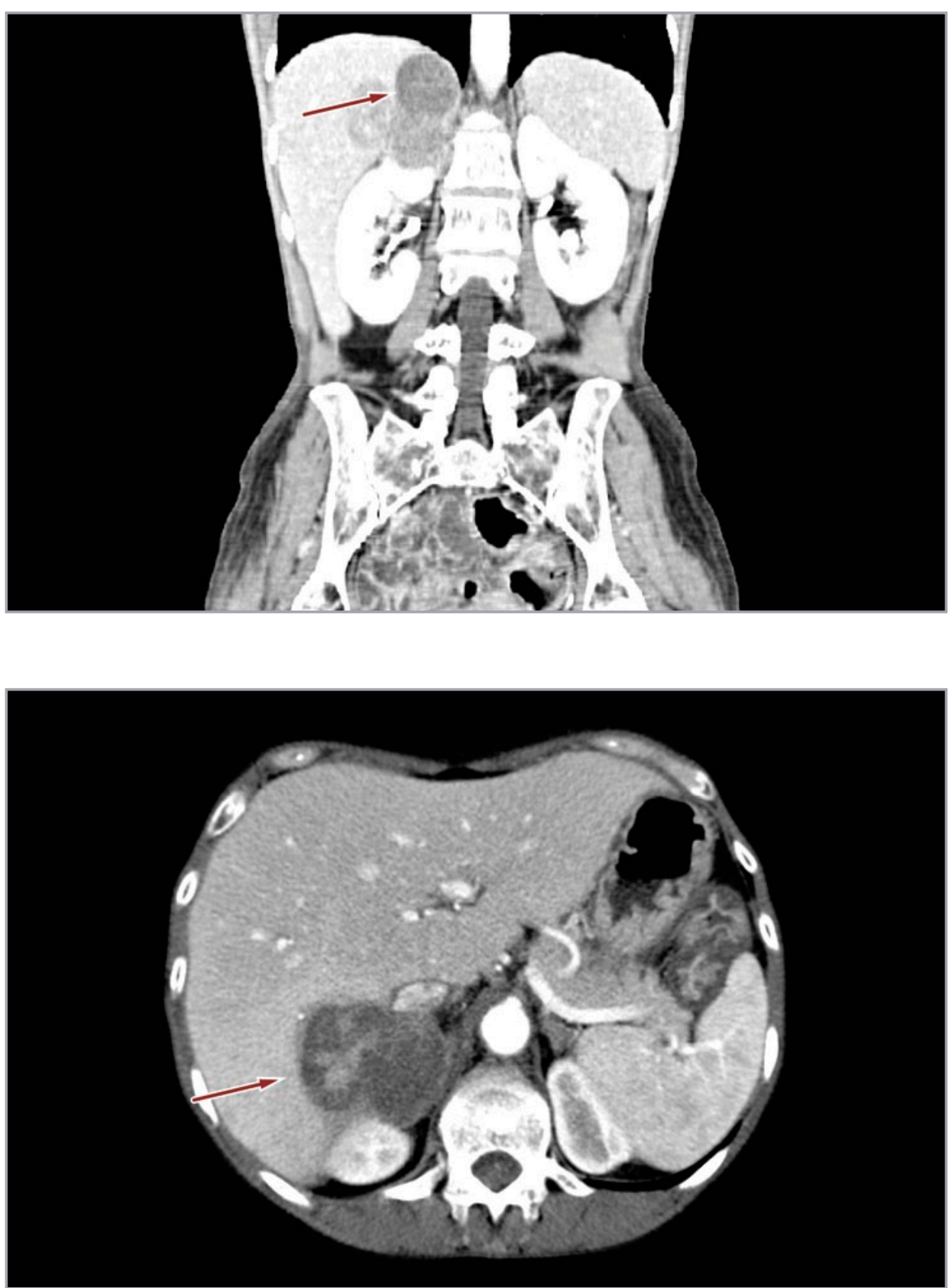

ultrasonography showed a nonspecific mass located around the upper pole of the right kidney and abdominal computed tomography revealed a right adrenal neoplasm measuring $45 \times 29 \mathrm{~mm}$ in diameter and bulging out toward the liver (Figures 1 and 2).

Physical examination revealed a tender palpable right upper quadrant mass. Laboratory studies were significant for anemia $(6.2 \mathrm{~g} / \mathrm{dl})$ and leukocytosis $\left(1.19 \times 10^{3} / \mu \mathrm{l}\right)$. Hormone panel including serum and urinary metanephrines, serum and urinary cortisol, plasma aldosterone, and serum adrenocorticotropic hormone was normal. Ten days after hospitalization, follow up chest-abdomen and pelvis CT scan re- vealed enlargement of the adrenal mass from $45 \times 29 \mathrm{~mm}$ to $65 \times 45 \mathrm{~mm}$. New bilateral lung nodules were also noted (Figures 3 and 4).

Therefore, fine-needle aspiration (FNA) was performed. Histological sections showed sheets of epithelioid cells in a fibrotic stroma and focal necrosis. Cells have eosinophilic cytoplasm, prominent nucleoli and frequent mitotic figures. These histologic features were consistent with malignant neoplasm. Further studies with pax8, cytokeratin 19 , claudin, calretinin, synaptophysin, chromogranin A, glypican-3, human melanoma black 45 and MART-1, and cytokeratin (AE1/AE3) were performed. The 

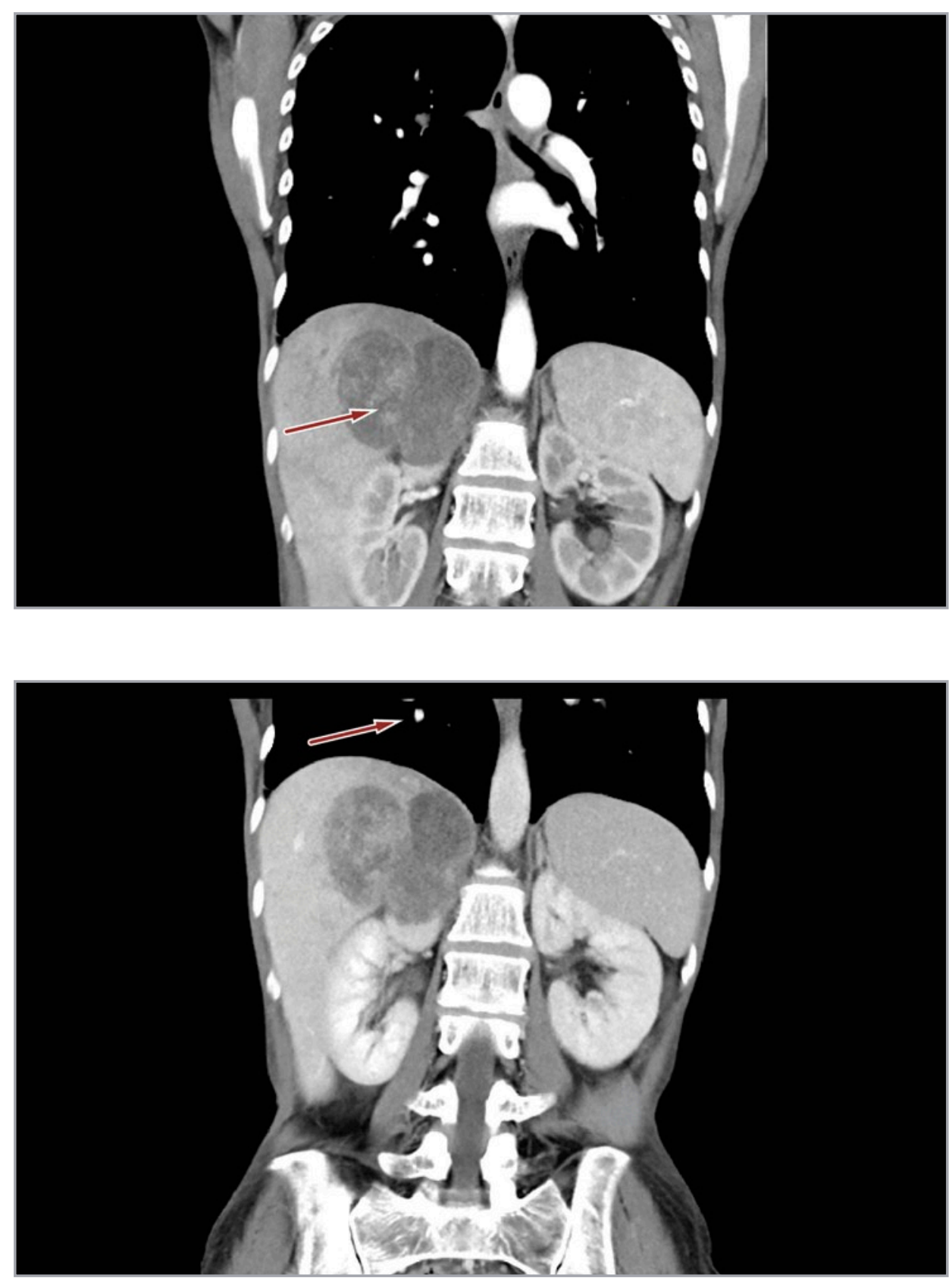

tumor cells were positive for cytokeratin and negative for all the remaining markers. A second panel of immunostains including CD31, cytokeratin, and ERG-1 was performed. Tumor cells were strongly positive for all (Figure 5). Hence, the diagnosis of

What should the clinician ask bim/herself or the patient

- Adrenal mass is rapidly growing?

- Are there general symptoms as asthenia, malaise, and mild fever?

- Hormonal activity is normal?
Figure 3. $C T$ scan revealing growing adrenal mass (red arrow) with extensive infiltration of liver and upper pole of kidney (longitudinal plan, ten days after hospital admission)

Figure 4. $C T$ scan showing evidence of lung metastasis (red arrow) in right pulmonary lobe (ten days after hospital admission) 

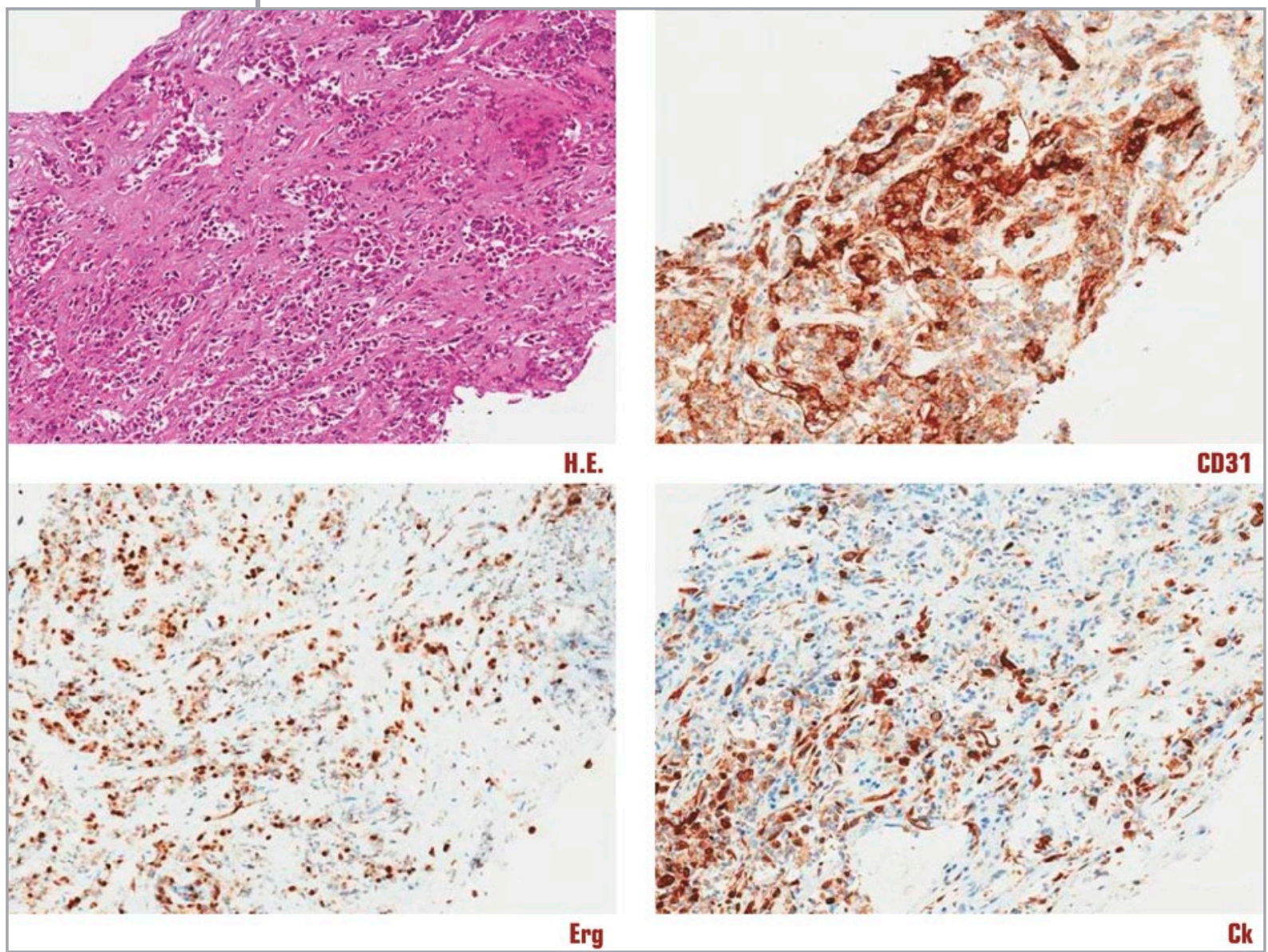

Figure $\mathbf{5 .}$

Hematoxylin-eosin

(H.E.) staining and immunobistochemical studies

$\mathrm{Ck}=$ cytokeratin been reported in literature. Nevertheless, among them, only 29 are available for full review in English, according to PubMed systemic research through $\mathrm{MeSH}$ terms (Table I) [4-33].

The etiology of EA remains unknown: apart from a case of exposure to arsenic [6] and a case of exposure to vynil chloride [29], the published case reports didn't succeed in identifying a clear correlation with the patients' exposure to carcinogens or with a significant incidence of other diseases, even though three patients had concomitant adrenal cortical adenoma $[26,31,32]$ (Table I).

\begin{tabular}{|c|c|c|c|c|c|c|c|c|}
\hline Case & $\begin{array}{l}\text { Bender } \\
\text { (age) }\end{array}$ & $\begin{array}{l}\text { Blinical } \\
\text { findings }\end{array}$ & $\begin{array}{l}\text { BT scan } \\
\text { findings }\end{array}$ & Side & $\begin{array}{l}\text { Other } \\
\text { disease }\end{array}$ & Therapy & Follow up & Ref. \\
\hline 1 & M (54) & Abdominal pain & $6 \mathrm{~cm}$ solid mass & L & None & $\begin{array}{l}\text { Adrenalectomy } \\
\text { + chemotherapy }\end{array}$ & $\begin{array}{l}\text { Relapse after } 7 \\
\text { months }\end{array}$ & 4 \\
\hline 2 & $F(54)$ & $\begin{array}{l}\text { Fatigue, weight } \\
\text { loss, paraneoplastic } \\
\text { syndrome }\end{array}$ & $\begin{array}{l}6 \mathrm{~cm} \text { soft tissue } \\
\text { upper pole right } \\
\text { kidney }\end{array}$ & $\mathrm{R}$ & None & Adrenalectomy & NED 6 months & 5 \\
\hline 3 & M (58) & Abdominal pain & $8 \mathrm{~cm}$ solid mass & $\mathrm{R}$ & $\begin{array}{l}\text { Chronic } \\
\text { arsenical } \\
\text { intoxication }\end{array}$ & Adrenalectomy & Died after surgery & 6 \\
\hline 4 & $M(41)$ & Epigastric pain & $\begin{array}{l}10 \mathrm{~cm} \text { rounded } \\
\text { mass }\end{array}$ & $\mathrm{R}$ & $\begin{array}{l}\text { Mesenteric } \\
\text { fibromatosis }\end{array}$ & $\begin{array}{l}\text { Adrenalectomy } \\
\text { + radiotherapy }\end{array}$ & NA & 7 \\
\hline 5 & $M(67)$ & Abdominal pain & $\begin{array}{l}\text { Inhomogeneous } \\
\text { mass }(13 \mathrm{~cm})\end{array}$ & $\mathrm{L}$ & None & Adrenalectomy & $\begin{array}{l}\text { Died } 2 \text { months for } \\
\text { lung mts }\end{array}$ & 8 \\
\hline 6 & M (85) & $\begin{array}{l}\text { Incidental findings } \\
\text { (autopsy) }\end{array}$ & NA & $\mathrm{R}$ & None & None & None & 9 \\
\hline 7 & $F(60)$ & Abdominal pain & NA & $\mathrm{R}$ & None & Adrenalectomy & NED 13 years & 9 \\
\hline
\end{tabular}




\begin{tabular}{|c|c|c|c|c|c|c|c|c|}
\hline \multicolumn{9}{|c|}{ Continued } \\
\hline Case & $\begin{array}{l}\text { Bender } \\
\text { (age) }\end{array}$ & $\begin{array}{l}\text { Clinical } \\
\text { findings }\end{array}$ & $\begin{array}{l}\text { OT scan } \\
\text { findings }\end{array}$ & Side & $\begin{array}{c}\text { Other } \\
\text { disease }\end{array}$ & Therapy & Follow up & Ref. \\
\hline 8 & $F(64)$ & Weight loss & $\begin{array}{l}10 \mathrm{~cm} \text { suprarenal } \\
\text { mass }\end{array}$ & L & None & Adrenalectomy & Died 12 months & 9 \\
\hline 9 & $F(60)$ & Left flank pain & Adrenal mass & $\mathrm{L}$ & None & Adrenalectomy & Died 2 months & 9 \\
\hline 10 & M (82) & Incidental finding & NA & NA & NA & Adrenalectomy & $\begin{array}{l}\text { Died } 24 \text { months (lung } \\
\text { mts) }\end{array}$ & 9 \\
\hline 11 & $F(45)$ & Cushing's syndrome & Adrenal mass & $\mathrm{R}$ & None & Adrenalectomy & NED 11 years & 9 \\
\hline 12 & M (56) & Fever, weakness & Adrenal mass & $\mathrm{R}$ & None & Adrenalectomy & $\begin{array}{l}\text { Died } 6 \text { months (lung } \\
\text { mts) }\end{array}$ & 9 \\
\hline 13 & $F(56)$ & Flank pain & Adrenal mass & L & None & $\begin{array}{l}\text { Adrenalectomy } \\
+ \text { chemotherapy }\end{array}$ & NED 6 years & 9 \\
\hline 14 & M (50) & Nausea, diarrhoea & $\begin{array}{l}5.5 \text { solid mass, } \\
\text { peritoneal mts }\end{array}$ & $\mathrm{R}$ & None & Adrenalectomy & Died 9 months (ileus) & 10 \\
\hline 15 & M (50) & Fever, lumbar pain & $\begin{array}{l}6 \mathrm{~cm} \text { solid mass } \\
\text { bone, liver mts }\end{array}$ & $\mathrm{R}$ & None & $\begin{array}{l}\text { Adrenalectomy } \\
+ \text { partial } \\
\text { hepatectomy }\end{array}$ & Died after surgery & 11 \\
\hline 16 & M (62) & Anorexia & $\begin{array}{l}\text { Adrenal mass (10 } \\
\mathrm{cm} \text { ) }\end{array}$ & $\mathrm{L}$ & None & Adrenalectomy & Died 7 weeks & 12 \\
\hline 17 & M (63) & Incidental finding & $3 \mathrm{~cm}$ solid mass & L & None & $\begin{array}{l}\text { Laparoscopic } \\
\text { adrenalectomy }\end{array}$ & NA & 13 \\
\hline 18 & M (70) & Abdominal pain & $8 \mathrm{~cm}$ solid mass & $\mathrm{R}$ & None & Adrenalectomy & Died 3 weeks & 14 \\
\hline 19 & M (34) & Cushing's syndrome & $\begin{array}{l}4 \mathrm{~cm} \text { irregular } \\
\text { mass }\end{array}$ & $L$ & $\begin{array}{l}\text { Pituitary } \\
\text { adenoma }\end{array}$ & Adrenalectomy & NED 2 years & 15 \\
\hline २० & $F(70)$ & Abdominal pain & $5 \mathrm{~cm}$ solid mass & $\mathrm{R}$ & $\begin{array}{l}\text { Cistobiliary } \\
\text { adenoma }\end{array}$ & Adrenalectomy & NED 18 months & 16 \\
\hline 21 & $M(61)$ & Abdominal pain & $\begin{array}{l}12 \mathrm{~cm} \text { irregular } \\
\text { mass }\end{array}$ & $\mathrm{R}$ & None & $\begin{array}{l}\text { Adrenalectomy } \\
+ \text { nephrectomy }\end{array}$ & NED 3 years & 17 \\
\hline 22 & M (71) & NA & NA & NA & NA & Adrenalectomy & NA & 18 \\
\hline 23 & M (60) & Abdominal pain & $\begin{array}{l}11 \mathrm{~cm} \text { solid and } \\
\text { cystic mass }\end{array}$ & $\mathrm{L}$ & $\begin{array}{l}\text { Colon } \\
\text { polyposis }\end{array}$ & $\begin{array}{l}\text { Adrenalectomy } \\
\text { + radiotherapy } \\
\text { + chemotherapy }\end{array}$ & $\begin{array}{l}\text { Died } 6 \text { months llung } \\
\text { mts) }\end{array}$ & 19 \\
\hline 24 & M (60) & NA & NA & NA & NA & $\begin{array}{l}\text { Adrenalectomy } \\
+ \text { chemotherapy }\end{array}$ & NED 3 years & 20 \\
\hline 25 & M (50) & Renal colic & $\begin{array}{l}7 \mathrm{~cm} \text { mass at the } \\
\text { upper pole kidney }\end{array}$ & $\mathrm{L}$ & None & $\begin{array}{l}\text { Adrenalectomy } \\
+ \text { nephrectomy }\end{array}$ & NED 12 years & 21 \\
\hline 26 & M (69) & Incidental & NA & NA & $\begin{array}{l}\text { Prostate } \\
\text { carcinoma }\end{array}$ & NA & NA & २2 \\
\hline 27 & M (49) & Incidental & $\begin{array}{l}\text { Large and cystic } \\
\text { mass }\end{array}$ & $\mathrm{R}$ & $\begin{array}{l}\text { Blunt } \\
\text { abdominal } \\
\text { trauma }\end{array}$ & Adrenalectomy & NED 1 year & 23 \\
\hline 28 & M (55) & $\begin{array}{l}\text { Abdominal mass, } \\
\text { weight loss }\end{array}$ & $10 \mathrm{~cm}$ solid mass & $\mathrm{R}$ & None & Adrenalectomy & $\begin{array}{l}\text { Died } 12 \text { months (lung } \\
\mathrm{mts} \text { ) }\end{array}$ & 24 \\
\hline 29 & $F(69)$ & Legs swellings & $\begin{array}{l}12.5 \mathrm{~cm} \\
\text { inhomogeneous } \\
\text { mass }\end{array}$ & $\mathrm{R}$ & $\begin{array}{l}\text { Chronic renal } \\
\text { failure }\end{array}$ & $\begin{array}{l}\text { Adrenalectomy } \\
+ \text { nephrectomy }\end{array}$ & NA & 25 \\
\hline 30 & M (35) & Hypertension & $\begin{array}{l}6 \mathrm{~cm} \\
\text { inhomogeneous } \\
\text { mass }\end{array}$ & $\mathrm{R}$ & $\begin{array}{l}\text { Adrenocortical } \\
\text { adenoma }\end{array}$ & $\begin{array}{l}\text { Laparoscopic } \\
\text { adrenalectomy }\end{array}$ & NED 2 years & 26 \\
\hline 31 & M (61) & Fatigue, weight loss & $\begin{array}{l}\text { Hypo-dense } \\
\text { space-occupying } \\
\text { lesion (PET) }\end{array}$ & $\mathrm{R}$ & Epicardial mts & Adrenalectomy & NA & 27 \\
\hline
\end{tabular}




\begin{tabular}{|c|c|c|c|c|c|c|c|c|}
\hline Case & $\begin{array}{l}\text { Pender } \\
\text { (age) }\end{array}$ & $\begin{array}{l}\text { Clinical } \\
\text { findings }\end{array}$ & $\begin{array}{l}\text { BT scan } \\
\text { findings }\end{array}$ & Side & $\begin{array}{l}\text { Other } \\
\text { disease }\end{array}$ & Therapy & Follow up & Ref. \\
\hline 32 & M (42) & Flank pain & $\begin{array}{l}\text { Hypervascular } \\
\text { solid mass } \\
(14 \mathrm{~cm})\end{array}$ & $\mathrm{R}$ & $\begin{array}{l}\text { Cystic lesion } \\
\text { of the adrenal } \\
\text { gland }\end{array}$ & $\begin{array}{l}\text { Adrenalectomy } \\
\text { and nephrectomy }\end{array}$ & $\begin{array}{l}\text { Died } 3 \text { months (liver } \\
\text { mts) }\end{array}$ & 28 \\
\hline 33 & M (68) & Left sided chest pain & $\begin{array}{l}\text { Heterogeneous } \\
\text { mass }(7 \mathrm{~cm})\end{array}$ & $\mathrm{L}$ & $\begin{array}{l}\text { Vynil chloride } \\
\text { exposition }\end{array}$ & $\begin{array}{l}\text { Laparoscopic } \\
\text { adrenalectomy }\end{array}$ & $\begin{array}{l}\text { Died } 7 \text { months (bone } \\
\text { mts) }\end{array}$ & 29 \\
\hline 34 & M (55) & $\begin{array}{l}\text { Abdominal mass, } \\
\text { weight loss }\end{array}$ & $14 \mathrm{~cm}$ solid mass & $\mathrm{L}$ & None & Adrenalectomy & NA & 30 \\
\hline 35 & $F(60)$ & Hypertension & $5 \mathrm{~cm}$ solid mass & $\mathrm{L}$ & $\begin{array}{l}\text { Adrenal } \\
\text { cortical } \\
\text { adenoma }\end{array}$ & $\begin{array}{l}\text { Laparoscopic } \\
\text { adrenalectomy }\end{array}$ & NED 9 months & 31 \\
\hline 36 & M (63) & Weight loss & $8 \mathrm{~cm}$ solid mass & $\mathrm{R}$ & $\begin{array}{l}\text { Adrenal } \\
\text { cortical } \\
\text { adenoma }\end{array}$ & Adrenalectomy & NA & 32 \\
\hline 37 & M (67) & Hypertension & $\begin{array}{l}16 \mathrm{~cm} \\
\text { heterogeneous } \\
\text { mass }\end{array}$ & $\mathrm{R}$ & $\begin{array}{l}\text { Left renal cell } \\
\text { carcinoma }\end{array}$ & Adrenalectomy & NED 12 months & 33 \\
\hline
\end{tabular}

Table I. Case reports on epithelioid angiosarcomas retrieved in PubMed

$\mathrm{L}=$ left; $\mathrm{mts}=$ metastasis; $\mathrm{NA}=$ not available; $\mathrm{NED}=$ no evidence of disease; $\mathrm{R}=$ right
The disease occurs more frequently in males $(M / F=28 / 9)$, ranges from 34 to 85 years of age, with a mean peak at 57 years.

Patients can either be asymptomatic or suffer from weight loss, slight fever, anorexia, fatigue, weakness, and chronic pain in the upper abdominal quadrants, as in our patient. No increase in adrenal gland hormones production is noted in most of the reported cases, even though two patients had Cushing's syndrome $[9,15]$ and in three patients the disease was discovered for the sudden onset of hypertension, despite none of them had increased plasmatic aldosterone or metanephrines [26,31,33].

Actually, CT scan is the most used radiological tool for diagnostic purpose, even if $\mathrm{F}^{18}$ FDG PET/CT may be useful too [27]. A1though adrenal angiosarcoma does not have a distinct gross pattern, a review of the literature showed that it tends to have a round, solid, and heterogeneous aspect. Frequently, it is a cystic mass and can range in size from $3 \mathrm{~cm}$ to $16 \mathrm{~cm}$ (Table I). Clinicians and pathologists should include primary adrenal angiosarcoma in the differential diagnoses list for large adrenal gland mass [34].

One can speculate that the rich adrenal vasculature may create a favorable milieu for hemorrhagic and necrotic changes, while the high mitotic index may explain both the solid pattern and the huge volume of the tumor that is often found.

In this case, the differential diagnosis includes metastatic malignancy and other primary adrenal tumors. Epithelioid angiosarcomas can imitate carcinomas morphologically and immune-phenotypically. Metastatic or primary melanoma can also show both epithelioid and spindled morphology. Among benign and malignant neoplasms that may simulate epithelioid angiosarcoma, there are adrenal adenoma undergoing massive hemorrhage and epithelioid hemangioendothelioma. Moreover, the diagnosis of angiosarcoma can be a challenge due to pathohistologic features mimicking intravascular papillary endothelial hyperplasia (IPEH - Masson's tumor). IPEH is a benign, reactive process that cannot be radiologically differentiated from other benign or malignant lesions [35].

Because of its rarity, in literature there is only one previous case of adrenal angiosarcoma diagnosed by fine-needle aspiration (FNA) [25]. In fact, owing to its epithelioid morphology, this tumor may be mistaken for other neoplasms. Sometimes, the difficult diagnosis may cause an insufficient surgical approach. If the tumor is confined to the adrenal gland, it is suggested to remove it, and also take the periadrenal fat tissue and pericaval or periaortic tissue out in order to eradicate any site of potential local tumor microinfiltration. Involved organs, such as liver, spleen, pancreas, kidney, or bowel must be removed [16]. Too often, patients undergo surgery before a proper diagnosis is made and the high incidence of local relapses may sometimes be explained by inadequate approaches. Laparoscopy may be used carefully in district surgeries: among the studied case reports, it was used in four patients with a follow up no longer than one year $[13,26,29,31]$. 


\begin{tabular}{|c|c|c|c|c|c|c|c|}
\hline Case & Gross finding & Ck & CD31 & CD34 & $\begin{array}{l}\text { Factor } \\
\text { UIII }\end{array}$ & Ki-67 & Ref. \\
\hline 1 & Solid and hemorrhagic mass & NA & NA & NA & NA & NA & 4 \\
\hline 2 & Solid mass with a central hemorrhagic mass & Pos & NA & NA & Pos & NA & 5 \\
\hline 3 & NA & NA & NA & NA & NA & NA & 6 \\
\hline 4 & Hemorrhagic cyst & Pos & NA & NA & Pos & NA & 7 \\
\hline 5 & Necrotic mass with nodules & NA & NA & NA & Pos & NA & 8 \\
\hline $6-13$ & Solid cystic mass & Pos & NA & Pos & Pos & NA & 9 \\
\hline 14 & NA & NA & NA & NA & NA & NA & 10 \\
\hline 15 & Hemorrhagic cystic lesion & Pos & Pos & Pos & Pos & NA & 11 \\
\hline 16 & Hemorrhagic mass & Pos & Pos & Pos & Pos & NA & 12 \\
\hline 17 & Hemorrhagic mass & Neg & NA & Pos & Pos & NA & 13 \\
\hline 18 & Solid mass replacing the adrenal gland & Pos & Pos & Pos & Pos & NA & 14 \\
\hline 19 & Multiple soft reddish nodules & Neg & Pos & Pos & Pos & $30 \%$ & 15 \\
\hline 20 & Hemorrhagic lesion & NA & Pos & NA & NA & NA & 16 \\
\hline 21 & Hemorrhagic cystic mass & Pos & Pos & Neg & Neg & NA & 17 \\
\hline २2 & NA & NA & NA & NA & NA & NA & 18 \\
\hline 23 & Cystic mass with hemorrhagic areas & Neg & Pos & Pos & Pos & NA & 19 \\
\hline 24 & Hemorrhagic cyst & Pos & Pos & Pos & NA & NA & 20 \\
\hline 25 & Bilocular cyst containing thick material & $\mathrm{Neg}$ & Pos & NA & Pos & NA & 21 \\
\hline 26 & NA & NA & NA & NA & NA & NA & 22 \\
\hline 27 & Hemorrhagic mass & NA & NA & NA & NA & NA & 23 \\
\hline 28 & Solid mass with hemorrhagic foci & Weak pos & Pos & Pos & Pos & NA & 24 \\
\hline 29 & Biopsy: epithelioid cell & Pos & Pos & Pos & NA & NA & 25 \\
\hline 30 & Lobulated mass with hemorrhagic foci & Pos & Pos & Pos & Pos & NA & 26 \\
\hline 31 & NA & NA & NA & NA & NA & NA & 27 \\
\hline 32 & Cystic changes with old hemorrhage & Pos & Pos & Neg & Neg & $60 \%$ & 28 \\
\hline 33 & Infiltrating hemorrhagic noduli & Focal pos & Pos & Neg & Pos & NA & 29 \\
\hline 34 & NA & NA & NA & NA & NA & NA & 30 \\
\hline 35 & Solid mass with hemorrhagic areas & Pos & Pos & Weak pos & Weak pos & NA & 31 \\
\hline 36 & Areas of hemorrhage and necrosis & Pos & Pos & $\mathrm{Neg}$ & NA & NA & 32 \\
\hline 37 & Hematoma & NA & Pos & Pos & Pos & NA & 33 \\
\hline
\end{tabular}

So far, diagnostic process is supported by histopathology and immunohistochemistry. Epithelioid angiosarcomas are morphological variants of angiosarcomas, in which polygonal endothelial cells with "epithelioid" appearance predominate and are often arranged in solid nests and sheets, mimicking carcinoma. Although irregular, anastomosing vascular channels are commonly identified within the lesion, supporting the diagnosis. Malignant cells stain positively for endothelial markers CD31, factor VIII, and Fli-1. CD34 is reported to be less sensitive even though it is present in about $40 \%$ of cases (Table II).
Most epithelioid angiosarcomas co-express cytokeratin and diagnostic errors may be promoted by immunohistochemical reactivity for this marker. In fact, cytokeratin reactivity may also occur in non-epithelial tumors like mesenchymal ones and the literature shows a lot of studies documenting the presence of cytokeratin in these tumors. Therefore, cytokeratin immunoreactivity may be considered as "aberrant expression" or "cross-reactivity" of this marker [36].

Surgery, combined with chemotherapy, represents the mainstay of treatment. Chemotherapy is preferably used in neoadjuvant setting to shrink the tumor and eventually
Table II.

Immunohistochemical and gross findings of reported cases

$\mathrm{Ck}=$ cytokeratin;

$\mathrm{NA}=$ not available 
prevent local or distant spread. In these cases, histological diagnosis is mandatory, before therapy and FNA may play an important role, because this tumor has not specific clinical or radiological patterns. Most active agents are anthracycline, ifosfamide, gemcitabine, and taxanes.

In advanced or metastatic disease, cytotoxic chemotherapy based on the same active drugs is the treatment of choice. Even if the response rate of angiosarcoma to these treatments is higher than other tumors, in most cases their dose-limiting toxic effects (mostly cardiac and neurological) do not allow to use these therapies longer than 6 months [3]. Thus, new and non-toxic drugs are strongly needed. Among new anti-angiogenetic therapies, activity of sorafenib, sunitinib, bevacizumab, and thalidomide has been recently described, obtaining response rates up to $15 \%[37,38]$. Especially in palliative setting, where the goal is to increase survival and preserve the quality of life, the sequential use of taxanes and gemcitabine could be, probably in most cases, more advisable than their combination [39].

\section{CONCLUSIONS}

Epithelioid adrenal angiosarcoma is a very rare tumor and only 37 cases are reported in scientific literature. It is very aggressive and has poor long term prognosis. Such data show that early diagnosis is mandatory. Nevertheless, early diagnosis is rarely made since the tumor may be asymptomatic or present with aspecific symptoms, like slight fever, anorexia, fatigue or general pain or discomfort in the upper parts of the abdomen. Actually, endocrine tests are not indicative and the radiology workup may suggest just an indistinct malignancy.

Even if histomorphological and immunohistochemical studies are time-consuming, they are an essential part of the definitive diagnosis and FNA may be an helpful tool to obtain a preoperative and definitive diagnosis.

Unfortunately, sometimes diagnosis is made when disease is advanced, with no therapeutic options, as happened in this case.

\section{Keypoints}

- Epithelioid adrenal angiosarcoma is a very rare and aggressive tumor

- Even if early diagnosis is mandatory, endocrine tests are not indicative and radiology workup shows an indistinct malignancy

- Histological diagnosis, supported by histopathology and immunohistochemistry, is essential for the best management performed by neoadjuvant chemotherapy and district surgery

- It may be important for clinicians to obtain a preoperative diagnosis by FNA

\section{REFERENCES}

1. Hart J, Mandavilli S. Epitheliod angiosarcoma. A brief diagnostic review and differential diagnosis. Arch Pathol Lab Med 2011; 135: 268-72

2. Fayette J, Martin E, Piperno-Neumann S, et al. Angiosarcoma, a heterogeneneous group of sarcomas with specific behavior depending on primary site: a retrospective study of 161 cases. Ann Oncol 2007; 18: 2030-6; https://doi.org/10.1093/annonc/mdm381

3. Young RJ, Brown NJ, Reed MW, et al. Angiosarcoma. Lancet Oncol 2010; 11: 983-91; https:// doi.org/10.1016/S1470-2045(10)70023-1

4. Kareti LR, Katlein S, Siew S, et al. Angiosarcoma of the adrenal gland. Arch Pathol Lab Med 1988; 112: 1163-5

5. Bosco PJ, Silverman ML, Zinman LM. Primary angiosarcoma of adrenal gland presenting as paraneoplastic syndrome: case report. J Urol 1991; 146: 1101-3

6. Livaditou A, Alexiou G, Floros D, et al. Epithelioid angiosarcoma of the adrenal gland associated with chronic arsenic intoxication? Pathol Res Pract 1991; 187: 284-9; https://doi.org/10.1016/ S0344-0338(11)80785-5

7. Ben-Izhac O, Auslander L, Rabinson S, et al. Epithelioid angiosarcoma of the adrenal gland with cytokeratin expression. Report of a case with accompanying mesenteric fibromatosis. 
Cancer 1992; 69: 1808-12; https://doi.org/10.1002/1097-0142(19920401)69:7<1808::AIDCNCR2820690724>3.0.CO;2-E

8. Fiordelise S, Zangrandi A, Tronci A, et al. Angiosarcoma of the adrenal gland. Arch Ital Urol Nefrol Androl 1992; 64: 341-3

9. Wenig BM, Abbondanzo SL, Heffess CS. Epithelioid angiosarcoma of the adrenal glands. A clinicopathologic study of nine cases with a discussion of the implications of finding "epithelialspecific" markers. Am J Surg Pathol 1994; 18: 62-73; https://doi.org/10.1097/00000478199401000-00006

10. Schwenk W, Sarbia M, Hass R, et al. Primary hemangiosarcoma as a rare form of an incidentally discovered mass of the adrenal glands. Dtsch Med Wochenschr 1994; 119: 217-21

11. Jochum W, Schroder S, Risti B, et al. Cytokeratin-positive angiosarcoma of the adrenal gland. Pathologe 1994; 15: 181-6; https://doi.org/10.1007/s002920050043

12. Sasaki R, Tachiki Y, Tsukada T, et al. A case of adrenal angiosarcoma. Nibon Hinyokika Gakkai Zasshi 1995; 86: 1064-7; https://doi.org/10.5980/jpnjurol1989.86.1064

13. Croitoru AG, Klausner AP, McWilliams G, et al. Primary epithelioid angiosarcoma of the adrenal gland. Ann Diagn Pathol 2001; 5: 300-3; https://doi.org/10.1053/adpa.2001.27917

14. Kruger S, Kujath P, Johannisson R, et al. Primary epithelioid angiosarcoma of the adrenal gland. Case report and review of the literature. Tumori 2001; 87: 262-5

15. Invitti C, Pecori Giraldi F, Cavagnini F, et al. Unusual association of adrenal angiosarcoma and Cushing's disease. Horm Res 2001; 56: 124-9

16. Pasqual E, Bertolissi F, Grimaldi F, et al. Adrenal angiosarcoma: report of a case. Surg Today 2002; 32: 563-5; https://doi.org/10.1007/s005950200099

17. Rodriguez-Pinilla SM, Benito-Belinches A, Ballestin C, et al. Angiosarcoma of adrenal gland. Report of a case and review of the literature. Rev Esp Patol 2002; 35: 227-32

18. Tousi-Sadr HR, Lam GW. Angiosarcoma of the adrenal gland. Ugeskr Laeger 2002; 164; 911-2

19. Artal EM, Gomez-Aracil V, Sole- Poblet JM, et al. Angiosarcoma epitelioide de suprarrenal. A proposito de un caso. Arch Esp Urol 2002; 55: 261-4

20. Sidoni A, Magro G, Cavaliere A, et al. Primary adrenal angiosarcoma. Pathologica 2003; 95: 60-3

21. Al-Meshan MK, Katchy KC. An unusual angiosarcoma. Med Princ Pract 2004; 13: 295-7; https://doi.org/10.1159/000079532

22. Galmiche L, Morel HP, Moreau A, et al. Angiosarcome primitif surralien. Annales de Pathologie 2004; 24: 371-3; https://doi.org/10.1016/S0242-6498(04)93987-9

23. Gambino G, Mannone T, Rizzo A, et al. Adrenal epithelioid angiosarcoma: a case report. Chir Ital 2008; 60: 463-7

24. Stavridis S, Mickovki A, Filipovski V, et al. Epithelioid angiosarcoma of the adrenal gland. Report of a case and review of the literature. Maced J Med Sci 2010; 3: 388-94

25. Schreiner AM, Hoda RS. Primary adrenal epithelioid angiosarcoma showing rhabdoid morphology in air-dried smears. Diagnostic Cytopathology 2011; 40: E162-E164; https://doi. org/10.1002/dc. 21690

26. Lepoutre Lussey C, Rousseau A, Al Ghuzlan A, et al. Primary adrenal angiosarcoma and functioning adrenocortical adenoma: an exceptional combined tumor. Eur J Endocr 2012; 166: 131-5; https://doi.org/10.1530/EJE-11-0791

27. Derlin TD, Claudiz TS, Habermann CR. Adrenal epithelioid metastatic to epicardium. Diagnosis by F18-FDG PET/CT. Clin Nucl Med 2012; 37: 914-5; https://doi.org/10.1097/ RLU.0b013e318262af6b

28. Sung JY, Ahn S, Kim SJ, et al. Angiosarcoma arising within a long standing cystic lesion of the adrenal gland. A case report. J Clin Oncon 2013; 31: e132-e136; https://doi.org/10.1200/ JCO.2012.44.0800

29. Criscuolo M, Valerio J, Gianicolo ME, et al. A vynil chloride-exposed worker with an adrenal gland angiosarcoma: a case report. Industrial Health 2014: 52: 66-70; https://doi.org/10.2486/ indhealth.2013-0044

30. Kedzierski L, Kawecka AH, Holecki M, et al. Angiosarcoma of the adrenal gland. Pol Arch Med We Wn 2013; 123: 502-3

31. Hendry S, Forrest C. Epithelioid angiosarcoma arising in a adrenal cortical adenoma: a case report and review of the literature. Int Jour Surg Pathol 2014; 22: 744-8; https://doi. org/10.1177/1066896914532541

32. Hayashi T, Gucer H, Mete O. A mimic of sarcomatoid adrenal cortical carcinoma: epithelioid angiosarcoma occurring in adrenal cortical adenoma. Endocr Pathol 2014; 25: 404-9; https:// doi.org/10.1007/s12022-014-9330-y 
33. Gusenbauer K, Ruzhynsky V, Kak I, et al. Angiosarcoma of the adrenal gland with concurrent controlateral advanced renal cell carcinoma: a diagnostic and management dilemma. Can Urol Assoc J 2015; 9: E302-E305

34. Yip L, Tublin ME, Falcone JA, et al. The adrenal mass: correlation of histopathology with imaging. Ann Surg Onc 2010; 17: 846-52; https://doi.org/10.1245/s10434-009-0829-2

35. Akdur NC, Donmez M, Gozel S, et al. Intravascular papillary endothelial hyperplasia: histomorphological and immunohistochemical features. Diag Pathol 2013; 8: 167; https://doi. org/10.1186/1746-1596-8-167

36. Swanson PE. Heffalumps, jagulars and cheshire cats: a commentary on cytokeratins and soft tissue sarcomas. Am J Clin Pathol 1991, 95(suppl.1): 2-7

37. Ray-Coquard I, Italiano A, Bompas E, et al. Sorafenib for patients with advanced angiosarcoma: a phase II Trial from the French Sarcoma Group (GSF/GETO). Oncologist 2012; 17: 260-6; https://doi.org/10.1634/theoncologist.2011-0237

38. Van Der Graaf WTA, Genderblom H. New systemic therapy options for advanced sarcoma. Curr Treat Options Oncol 2012: 13: 306-17; https://doi.org/10.1007/s11864-012-0196-2

39. Stacchiotti S, Palassini E, Sanfilippo R, et al. Gemcitabine in advanced angiosarcoma: a retrospective case series analysis from the Italian Rare Cancer Network. Ann Oncol 2012; 23: 501-8; https://doi.org/10.1093/annonc/mdr066 